\title{
Advocating for Structural Change? Exploring the Advocacy Activities of Immigrant-Serving Organizations in an Unwelcoming Policy Context
}

\author{
Benjamin Roth \\ Seo Yeon Park \\ Breanne Grace
}

\begin{abstract}
The growth of the immigrant population in the United States has prompted a recent increase in the number of restrictive immigration policies at the state and local levels. The literature on policy advocacy and social service organizations suggests that these local providers can engage in political activities that challenge the restrictive nature of these contexts. This qualitative study explored how immigrant-serving social service organizations engage in policy advocacy in a state with restrictive, anti-immigrant policies. In-depth interviews with directors of 50 service providers in South Carolina clearly indicate a tension between the need for policy advocacy and the risks associated with engaging in such activities. Fifty percent (50\%) of the providers in our sample reported engaging in some form of policy advocacy. However, their policy advocacy activities were often indirect, non-confrontational, and episodic. Most were engaged in coalitions and other forms of indirect advocacy tactics. We discuss implications for the social work profession and recommendations for future research, including the need to further explore the impact of policy advocacy efforts on changing the policy landscape in places that are unwelcoming to immigrants.
\end{abstract}

Keywords: Immigrants; immigration; policy advocacy; social service organizations; immigrant new destinations

The size of the immigrant population in the United States has grown dramatically in recent decades. For the first time in over a century, U.S. immigrants now represent $13.5 \%$ of the total population, including an unprecedented 11 million who are unauthorized (Migration Policy Institute, 2018). These demographic changes have converged with shifts in immigrant settlement patterns such that immigrants are increasingly moving to "new destinations" such as small midwestern towns and the American Southeast, injecting new diversity into places that have not been home to immigrant newcomers in recent memory (Massey, 2008). However, the convergence of these factors has also prompted a flurry of restrictive immigration policies at the state and local levels (Varsanyi, Lewis, Provine, \& Decker, 2012). In effect, while federal laws exclusively control the flow of legal immigrants into the United States, a patchwork of state and local policies regulating processes of immigrant integration have fundamentally altered the places where immigrants settle-i.e., the local receiving context. These laws include English-only ordinances, agreements between local law enforcement and federal immigration authorities that target unauthorized immigrants, and policies that restrict immigrant access to driver's licenses and higher education.

The assemblage of local anti-immigrant policies and practices form an influential

Benjamin J. Roth, PhD, MSW, is an Assistant Professor at the University of South Carolina College of Social Work, Columbia, SC 29208. Seo Yeon Park, PhD, is a researcher at HanYang University in South Korea. Breanne G. Grace, PhD, is an Assistant Professor at the University of South Carolina College of Social Work. 
aspect of the local receiving context, which shapes whether and to what extent immigrants adapt economically, socially, and culturally to their new home (Portes \& Rumbaut, 2006). Just as more "welcoming" contexts can facilitate processes of immigrant integration, places with restrictive anti-immigrant policies can pose an impediment. Local immigrant-serving organizations can provide a buffer against unwelcoming policy environments, offering services and resources that help immigrants with the process of adjusting socially and economically (Cordero-Guzman, 2005). There is some evidence that local immigrantserving organizations may also engage in policy advocacy to challenge state and local antiimmigrant laws (de Graauw, 2008), but these studies tend to focus on more traditional receiving contexts such as San Francisco (de Graauw, 2008, 2014) or Washington, D.C. (Frasure \& Jones-Correa, 2010) where there is a relatively large concentration of such organizations (de Leon, Maronick, De Vita, \& Boris, 2009). Limited research has focused on the policy advocacy activities of immigrant-serving organizations in new destination areas that have adopted restrictive anti-immigrant policies.

To address this gap, we explore how immigrant-serving organizations engage in policy advocacy activities in South Carolina, a state with some of the harshest anti-immigrant laws in the country. In keeping with the literature on this topic, we define the term "social service providers" to include local entities that deliver an actual service or program (such as mental health treatment) and "immigrant-serving organizations" to be the subset of social service providers that report delivering services to immigrants (Roth \& Allard, 2016; Roth, Gonzales, \& Lesniewski, 2015). By “local” we mean that the service delivery model is direct, not through the phone, internet, or mail. Clients must travel to these organizations to access services (or the provider must travel to the community to meet with the client) (see Allard, 2009). We use the terms "social service providers", "immigrant-serving organizations" and "providers" interchangeably throughout this article given that all of the organizations referenced in this study identify as local organizations that deliver services to immigrants.

We aim to address two primary questions: Why do some immigrant-serving organizations engage in policy advocacy activities to advance the rights of immigrants in a harsh immigration policy context, while others do not? And, among those who are active in policy advocacy, what types of actions and strategies do they take? Our framework draws on the literature of immigrant integration (Alba \& Nee, 2003; Portes \& Rumbaut, 2006) and social service providers as policy advocates (Mellinger, 2014b; Mosley, 2012). This article provides empirical insights into the field of immigrant-serving social service providers engaged in policy advocacy, as well as recommendations for how the field of social work can advance immigrant rights in a restrictive policy environment.

\section{Background}

\section{International migration and theories of integration}

International migration (or immigration) is the movement of people across nation-state borders (Massey et al., 1994). The literature on immigration spans all aspects of the migratory process, including why immigrants leave, their experience through transit countries, and what happens when they arrive in the destination country (Castles \& Miller, 
2009). The latter is often referred to as immigrant integration: the process by which immigrants adjust socially, economically, and politically to the places where they settle (Marrow, 2005). Contemporary sociological theories of immigrant integration emphasize that this process unfolds incrementally and at different rates, depending on a range of factors at various levels, whether individual, familial, or institutional (Alba \& Nee, 2003; Portes \& Zhou, 1993). Importantly, contemporary theories of immigrant integration emphasize that this adaptive process is also impacted by the structural characteristics of the receiving context-the places where immigrants settle. Factors such as racial discrimination, xenophobia, residential segregation, and the uneven quality of public schools all influence the opportunities for integration that are available to immigrants, and they will look different depending on the national context where they settle. Thus, according to Portes and Rumbaut (2006), the social mechanisms that perpetuate exclusion for certain members of a given host society mean that some immigrant groups are able to more easily integrate into different social strata depending on characteristics such as phenotype and human capital, as well as the federal laws governing which immigrants are allowed to enter the country. For instance, the pace of integration and opportunities for social mobility are more constrained for labor migrants and undocumented immigrants than for those who arrive on work visas to fill professional jobs in the tech sector (Portes \& Rumbaut, 2006).

\section{Immigrant new destinations}

Theories of immigrant integration have traditionally conceptualized the receiving context at the national level, because federal governments are typically responsible for enacting legislation that governs migratory flows (Portes \& Rumbaut, 2006). However, with the emergence of immigrant new destinations, a rapidly growing literature has begun to examine how local and state authorities are passing laws that influence immigrant settlement patterns and the process of integration. In contrast to traditional immigrant gateways such as New York and Los Angeles, immigrant new destinations are places that have only recently become home to immigrant newcomers (Massey, 2008; Singer, 2013). Immigrants have moved in growing numbers to suburbs, small towns, rural areas, and regions such as the Midwest and Southeast in search of employment and a lower cost of living (Massey, 2008). The dispersion of immigrant settlement in the 1990s and early 2000s rapidly changed the demographic balance across the United States (Massey, 2008), and their presence stirred a mixture of responses from established residents.

At one extreme were state and local governments that enacted laws and policies meant to deter immigrants from settling permanently (Mitnik \& Halpern-Finnerty, 2010; Varsanyi, 2008), a strategy referred to as "attrition through enforcement" (Kobach, 2008). A combination of local government policies (de Graauw, 2014; Mitnik \& HalpernFinnerty, 2010; Ramakrishnan \& Wong, 2010; Varsanyi, 2008), anti-immigrant activism (Varsanyi, 2011), and resistance by public bureaucrats (Lewis, Provine, Varsanyi, \& Decker, 2013; Marrow, 2009) has come to obstruct immigrant integration in new destinations with a restrictivist response to immigrants. As a result, immigrants in new destinations with harsh anti-immigrant laws experience higher levels of neighborhood segregation than in traditional gateways (Hall, 2013; Lichter, Parisi, Taquino, \& Grice, 
2010), and face pronounced barriers to services such as healthcare, bilingual education, housing, and English-language classes (Cabell, 2007; Marrow, 2009).

\section{Intermediary organizations as policy advocates}

While poverty and legal status create common obstacles to the social and economic inclusion and well-being of immigrants, immigrant-serving organizations can play a significant role in aiding immigrants' lives as they provide immigrants with practical help, represent immigrants for political or cultural purposes, and advocate for them as needed (Cordero-Guzman, 2005). Such organizations provide services related to educational, medical, religious, and other practical needs, but they can also be agents of political incorporation, as they work to shape political agendas and facilitate immigrants' political participation (de Graauw, 2008). Therefore, understanding these local organizations and their impact is critical to how we conceptualize immigrant integration in unwelcoming policy environments, and by extension, how we understand the role of social service organizations in advocating for and protecting immigrant rights.

There is general agreement among scholars about the importance of policy advocacy by "nonprofit organizations" (a broad term that is often used in this literature which includes local social service providers as we defined them) (Berry, 2005; Reid, 2000). Yet, there appears to be less consensus on what policy advocacy actually is. Reid (2000) states "there is no agreement on which activities constitute advocacy," but "it broadly describes the influence of groups in shaping social and political outcomes in government and society" (p. 6). Boris and Mosher-Williams (1998) argue that the definition of advocacy is often too narrow, restricted to rights-oriented groups, and limited to legislative advocacy. For example, many organizations assume that policy advocacy is limited to lobbying. Lobbying is one type of policy advocacy, defined by the IRS as direct or indirect appeals to governing bodies in order to influence specific legislation (Mosley, 2013). However, the growing literature on this topic suggests that nonprofit organizations engage in a wider range of activities related to policy advocacy. Although nonprofits cannot engage in certain lobbying activities, such as endorsing specific candidates, they are allowed to advocate for causes, programs, and populations and to lobby elected officials to adopt certain positions on particular policies or issues. While nonprofit organizations are able to hold forums, sponsor debates, host candidates at their offices, register voters, and engage in other nonpartisan activities, these organizations tend to find such rules vague (Mosley, 2013). To avoid any unintentional violations, they tend to steer clear of political advocacy altogether (Berry, 2005). The potential implications of this inaction are significant given that, in our current devolved welfare state, "these are the only organizations that have an incentive to organize, mobilize, and advocate on behalf" of marginalized groups (Berry, 2005, p. 571).

For the purposes of our study, Mosley (2013) adopts a broader definition of policy advocacy among social service organizations as "advocacy that is directed at changing policies or regulations that affect practice or group well-being” (p. 231). This definition of policy advocacy is not necessarily confrontational. Berry and Arons (2003) contend that less aggressive tactics (through partnership with government, for example) are still an effective way to shape policies and programs. Based on Mosley's (2013) definition, then, 
policy advocacy might be focused on getting additional funding to serve clients, or on the interests of clients themselves. Policy advocacy may also take place within organizational collaborations, coalitions or associations, particularly for smaller organizations with fewer resources to participate in policy advocacy (see Mellinger, 2014b).

Mosley (2013) identifies three trends in contemporary policy practice that are influencing the way social service providers engage in advocacy and help explain why a growing number are doing so. First, increased reliance on government funding means that these providers are more often interacting with political actors whose decisions impact the clients they serve (Mosley, 2010, 2011). Second, shrinking availability of government funding, especially state and local units, means that the local safety net must increasingly rely on social service providers for assistance and expertise (Allard, 2009; Mosley, 2013). Third, the growth of public agencies working together with private stakeholders is associated with growth in the number of advisory boards, task forces, and other such partnerships (Mosley, 2013). The goal of this type of collaborative governance is to improve transparency, efficiency, and government accountability, but a byproduct is that social service providers have more influence in the policy process.

Based on this broad definition of policy advocacy, many organizations engage in these types of activities. Mosley (2010) found that 57\% of social service organizations report some type of advocacy involvement, and qualitative interviews revealed that the majority (93\%) were involved in policy advocacy in some way (Mosley, 2013). Similarly, Mellinger (2014a) found that 65\% engaged in advocacy. However, the service providers in these studies do not engage in policy advocacy very frequently (Mellinger, 2014a; Mosley, 2013) — a pattern corroborated across the literature (Almog-Bar \& Schmid, 2014)—despite its importance for the well-being of the clients they serve.

While important scholarly work has advanced our understanding of policy advocacy and why social service providers engage in it (or not), these studies tend to focus narrowly on specific service domains (such as homelessness) in large cities (Mosley, 2010), or more broadly across organizations in a given region with little consideration for the specific policy context that may be the focus of their advocacy efforts (Mellinger, 2014a). We are unaware of research that has examined the policy advocacy activities of local immigrantserving organizations in restrictive policy contexts, how they interpret the particular local and national challenges they face, or how they integrate advocacy into their array of organizational activities.

\section{South Carolina context}

South Carolina is a new immigrant destination that has adopted restrictive, antiimmigrant policies in response to rapid growth of its immigrant population. The number of immigrants in South Carolina doubled from 2000 - 2015. This was nearly three times the national rate during this period (39\%), and five times the rate of the state's native-born population (20\%) (See Table 1; Migration Policy Institute, 2018). Nearly one in five immigrants in South Carolina (18\%) has arrived since 2010; 61\% are non-citizens, and an estimated $42 \%$ are unauthorized. Immigrants in the state are more likely than their nativeborn neighbors to be poor, and 37\% do not have health insurance. While the data for 
unauthorized immigrants is not available, the disadvantages are even greater for immigrants who are non-citizens (Marrow, 2013; Yoshikawa \& Kalil, 2013).

Table 1. South Carolina Immigrant Demographics, 2015

\begin{tabular}{lrrrrr}
\hline & \multicolumn{2}{c}{ SC } & & \multicolumn{2}{c}{ United States } \\
\cline { 2 - 3 } \cline { 5 - 6 } & \multicolumn{1}{c}{$\#$} & $\%$ & & $\#$ & $\%$ \\
\hline Demographics & & & & & \\
$\quad$ Immigrant (foreign born) & 232,749 & $5 \%$ & & $43,290,372$ & $14 \%$ \\
$\quad$ Non-citizen & 140,748 & $61 \%$ & & $22,593,269$ & $52 \%$ \\
$\quad$ Unauthorized & 98,000 & $42 \%$ & & $11,009,000$ & $25 \%$ \\
$\quad$ Immigrant \% change 2000 - 2015 & & $101 \%$ & & & $39 \%$ \\
$\quad$ Native born \% change 2000- 2015 & & $20 \%$ & & & $11 \%$ \\
\hline Region of Birth & & & & & \\
$\quad$ Africa & 8,771 & $4 \%$ & & $2,062,257$ & $5 \%$ \\
$\quad$ Asia & 58,362 & $25 \%$ & & $13,249,179$ & $31 \%$ \\
$\quad$ Latin America & 118,663 & $51 \%$ & & $22,111,409$ & $51 \%$ \\
\hline Period of Entry & & & & \\
$\quad$ 2000 - 2009 & 81,288 & $35 \%$ & & $12,069,227$ & $28 \%$ \\
$\quad$ Since 2010 & 42,100 & $18 \%$ & & $6,746,822$ & $16 \%$ \\
\hline Poverty rate & & & & \\
$\quad$ Foreign born & & $21 \%$ & & \\
$\quad$ Foreign born - non-citizen & & $28 \%$ & & & $23 \%$ \\
$\quad$ Native born & & $17 \%$ & & & \\
\hline Source: Migration Policy Institute, 2018 & & & &
\end{tabular}

In response to the rapid growth of the immigrant population and in the wake of federal inaction on comprehensive immigration reform, South Carolina enacted the Illegal Immigration Reform Act in 2008 and Senate Bill 20 in 2011. The first law restricts undocumented immigrants from public benefits and bars them from public higher education (Illegal Immigration Reform Act, 2008). The second law is fashioned after Arizona Senate Bill 1070, and includes a "papers please" provision which requires police to report individuals who do not have identification indicating they are in the country legally (National Immigration Law Center, 2014). The law also includes a provision for a statewide immigration enforcement unit - the only one of its kind in the U.S. (Largen, 2012). In 2014 a civil rights coalition successfully challenged Senate Bill 20, permanently blocking key provisions that criminalized interactions with unauthorized immigrants (National Immigration Law Center, 2014). However, other aspects of the law were not overturned, and both laws remain. In sum, South Carolina provides a useful empirical window into the policy advocacy activities of immigrant-serving social service providers because it has one of the fastest-growing immigrant populations in the country and some of the most hostile anti-immigrant policies of any state in the nation.

\section{Data and Methods}

Data for this analysis comes from the Immigrant Access Project (IAP), a mixed methods study of social service providers conducted by the authors in 2015. The 
quantitative portion of the project was an on-line survey of immigrant-serving organizations across South Carolina. We then conducted in-depth interviews with executive directors and program coordinators from a purposive sub-sample of 50 immigrant-serving organizations. This paper is based on analyses from the qualitative portion of the study.

\section{Sample}

It can be difficult to identify immigrant-serving organizations (Gleeson \& Bloemraad, 2012), in part because so few identify as such when reporting to the IRS (Hung, 2007). This is also the case in South Carolina because there is no comprehensive database of immigrant-serving organizations in the state. Therefore, we used a range of data sources to identify immigrant-serving organizations (Allard \& Roth, 2010), which we defined functionally as direct service providers that serve immigrant clients (Cordero-Guzman, 2005; Martin, 2012). This definition includes both ethnic and immigrant organizations (Hung, 2007), as well as mainstream providers (Roth \& Allard, 2016). Sources for building our sample included IRS 990 data that identified immigrant and ethnic organizations; regional and state resource guides that listed organizations that serve immigrants; and the referral database of a statewide immigrant-serving organization. This yielded a database of 599 service providers comprised primarily of nonprofits (both secular and faith-based), as well as a small number of public agencies (such as county food pantries) and for-profit entities. We then narrowed the sample to 319 entities by eliminating organizations that did not provide direct services in South Carolina, or for which no current contact information was available. We emailed executive directors of these 319 entities with an invitation to participate in the on-line survey. In all, 183 providers responded, for a response rate of $57 \%$. Data for this study came from in-depth interviews with a purposive sample of 50 survey respondents which we selected based on organization type, size, and primary service focus (e.g., anti-poverty, education, legal services, etc.) to maximize variation (Table 2).

Table 2. Sample Characteristics of Organizations in Qualitative Phase $(n=50)$

\begin{tabular}{lrr}
\hline & $\#$ & $\%$ \\
\hline Type of organization & & \\
Public & 11 & $22 \%$ \\
Secular non-profit & 31 & $62 \%$ \\
Faith based non-profit & 6 & $12 \%$ \\
$\quad$ For-profit & 2 & $4 \%$ \\
\hline Type of service provider & & \\
Health (health, mental health and substance abuse) & 10 & $20 \%$ \\
Anti-poverty (housing, employment, cash assistance, food, general referral) & 14 & $28 \%$ \\
Education (GED, afterschool, parenting classes, early childhood, ESL) & 16 & $32 \%$ \\
Legal services & 4 & $8 \%$ \\
Child and family welfare (youth programs, domestic violence, etc.) & 6 & $12 \%$ \\
\hline Organization size & & \\
Small (fewer than 5 full-time employees) & 20 & $40 \%$ \\
Medium (between 5 - 20 full-time employees) & 19 & $38 \%$ \\
Large (more than 20 full-time employees) & 11 & $22 \%$ \\
\hline
\end{tabular}




\section{Data collection and analysis}

We conducted in-depth interviews with executive directors, program administrators, and other leaders at these organizations. All interviews were conducted by phone. Interviews ranged in length from 30-60 minutes and were audio-recorded and transcribed. Interview questions addressed organizational history and mission; capacity (budget, revenues, and number of clients served); and details about general services. We also explored the nature and scope of their services for immigrants, and how these programs had evolved. Finally, and most relevant to this analysis, we asked questions about their view of South Carolina as a receiving context for new immigrants, their involvement with policy advocacy, and their involvement with coalitions that address immigrant rights concerns.

All transcripts were coded by the authors and analyzed using NVivo11, a qualitative data analysis software. Our codebook was informed by theories of immigrant integration (Portes \& Rumbaut, 2006) and social service organizations as intermediaries (Mosley, 2013). Codes included "advocacy," "barriers," "mediating role," "strategies," and "organizational partnerships." Analysis focused on text where respondents discussed their view of South Carolina as an immigrant-receiving context and policy advocacy broadly defined (Mosley, 2013). This included respondents' answers to questions such as "How would you describe South Carolina and the welcome that it gives to immigrants?," as well as several questions about advocacy, including "Have you ever participated in organizational activities or conversations related to immigrant rights in South Carolina?” and "Do you think advocating for immigrant rights differs from advocacy for other issues or populations in South Carolina?” These broad questions were followed by a series of probes that asked respondents to describe the nature of these activities, their motivation for participating in them (or not), and their perceptions of the effectiveness these efforts.

Looking across code domains we constructed a series of matrices to identify themes and patterns that guided subsequent analyses (Miles \& Huberman, 1994). Themes emerged using the constant comparative approach (Glaser, 1965) which involved comparing data from different respondents to identify common indicators. We structured our findings section based on the themes that emerged from this analysis. Themes include structural barriers to advocacy that are conditioned by the restrictive context of South Carolina, as well as the strategies organizations take in response to these barriers, including indirect advocacy through coalitions and networks.

All three authors were intimately involved with each stage of the data collection and analysis phases. The first two authors were primarily responsible for the coding process. This included weekly meetings to discuss the development of the theory-informed codebook and inconsistencies in how each author applied it to the data. Regular meetings during all phases of the project addressed code book development, the coding process, and interpretation, ultimately enhancing the confirmability of the research findings (Lietz \& Zayas, 2010).

\section{Findings}

We have organized our findings based on the key themes that emerged from our data. 
In this section, therefore, we begin by providing insights into the context of South Carolina from the perspective of the social service providers in our study. This provides an important backdrop for understanding whether they engage in advocacy activities. We then summarize the types of advocacy activities they identify, as well as the barriers they perceive to engaging in advocacy on behalf of immigrants. The final theme addresses their strategies for overcoming these barriers.

\section{South Carolina: A context for immigrant advocacy}

There was general agreement among the providers in our study that South Carolina is an unwelcoming receiving context for immigrants. Some respondents said the receiving context is nuanced rather than monolithic, describing South Carolina as a place that, while primarily unwelcoming, has_as one respondent stated_- "pockets of welcome.” These providers tended to describe parts of their respective city as more receptive to discussing immigration and immigrant rights. However, the majority of our respondents were more sweepingly negative in their assessment. For example, the Executive Director of an antipoverty organization explained that the climate towards immigrants is "hostile" in South Carolina so you need to "tread lightly" before even broaching the topic. Because tension over the issue "involves everything from religion to politics," he explains, "sometimes you feel like your hands are tied or your mouth is taped closed." The Director of a small health clinic stated that the unwelcoming nature of the state context means that "people don't fight for immigrant rights as much as they do for other people's rights.” Respondents repeatedly emphasized that the biases against immigrants are pervasive. The Executive Director of a child welfare agency stated the predominant perspective in South Carolina is that "all immigrants are from Mexico [and] they think all immigrants are illegal...so it's just the fact that we have so much to teach.”

\section{Advocating for immigrants}

We asked respondents "Have you ever participated in organizational activities or conversations related to immigrant rights?” We probed for more information, asking about the nature of their involvement and why they got involved, or why they have not gotten involved. We also asked whether they are involved with any coalitions that engage in advocacy for immigrants, followed by a similar series of probes. Consistent with other studies of social service providers and policy advocacy activities (MacIndoe \& Whalen, 2013; Mellinger, 2014b; Mosley, 2012), 50\% of the providers in our sample reported engaging in some form of policy advocacy (Table 3). We organized these activities into "independent" and "coalition" based on whether organizations were engaged in policy advocacy on their own or in collaboration with other entities. Some organizations reported both types of activities, but certain types of organizations were more likely to report involvement in at least one type. Among faith-based providers, for example, $67 \%$ reported engaging in at least some type of policy advocacy, and anti-poverty and legal service providers were more likely than some other provider types to report involvement in policy advocacy. Some organizations stated that they were involved in immigrant rights coalitions, while others stated their organization independently engaged in advocacy efforts to address immigrant rights. Still other participants reported engaging in both 
independent activities and coalition-based activities.

Table 3. Types of Immigrant-Serving Organizations and Their

\begin{tabular}{|l|c|c|c|}
\hline \multirow{2}{*}{ Advocacy Activities } & & \multicolumn{2}{|c|}{ Engaged in Policy } \\
\cline { 3 - 4 } & $n$ & $\#$ & $\%$ \\
\cline { 3 - 4 } & & & \\
Type of organization & 11 & 3 & $27 \%$ \\
Public & 31 & 18 & $58 \%$ \\
Secular non-profit & 6 & 4 & $67 \%$ \\
Faith based non-profit & 2 & 0 & $0 \%$ \\
For-profit & & & \\
Type of service provider & 10 & 5 & $50 \%$ \\
Health & 14 & 8 & $57 \%$ \\
Anti-poverty & 16 & 6 & $38 \%$ \\
Education & 4 & 4 & $100 \%$ \\
Legal services & 6 & 2 & $33 \%$ \\
Child and family welfare & & & \\
\hline Organization size & 20 & 8 & $40 \%$ \\
Small & 19 & 12 & $63 \%$ \\
Medium & 11 & 5 & $45 \%$ \\
Large & $\mathbf{5 0}$ & $\mathbf{2 5}$ & $\mathbf{5 0 \%}$ \\
\hline Total & & \\
\hline *Percentages represent the share of organizations of a given type that reported \\
at least one type of advocacy activity (independent, coalition, or both).
\end{tabular}

However, while half of the immigrant-serving providers in our sample reported engaging in some form of policy advocacy, many qualified the nature or extent of their involvement. Therefore, in the sections that follow we explore first why more providers do not participate in policy advocacy. We then take up the case of those organizations in our sample that engage in advocacy to better understand the types of advocacy activities they engage in, and how they are able to avoid common barriers to advocacy.

\section{Why some providers do not engage in policy advocacy}

If there is general agreement among the organizations in our sample that immigrant rights in South Carolina are particularly vulnerable, why do half of the providers report that they do not engage in policy advocacy to address these structural concerns? The most common reason was a lack of resources. The Executive Director of a small child welfare organization said that she is aware of some current anti-immigrant legislation but has not stayed abreast of the larger question of policy advocacy and immigrant rights. She has "not had the time, [and has] chosen not to be stressed out by it," even though she views that these policies are problematic. Her view is that they "are written by people who have no idea” of the reality experienced by immigrants. Another respondent stated more bluntly that her organization does not have the resources: "I really think that an agency like ours should be involved in advocacy, but you need support for that and you need time to do that and you need to dedicate a staff person to that." She is the Executive Director of an 
organization that addresses the basic needs of immigrants and other clients, but has only three full-time staff members.

Consistent with other studies (Mellinger, 2014a; Mosley, 2010), larger providers in our sample were more likely to engage in some form of policy advocacy (see Table 3), but the rationale for noninvolvement among these organizations was similar-even for involvement on local coalitions focused on immigrants and immigrant rights. According to the Director of a literacy center, he refuses to join a coalition if he cannot be actively involved. Contributing in this way would demand time that he currently does not have: "Right now I work about 60 hours a week and, you know, just stepping into another group is hard."

Several organizations stated that it would be politically risky for them to speak out about immigrant rights, inconsistent with their organizational mission, or potentially problematic for (some) members of their board. This was the case for the program manager for an organization that provides ESL services for immigrants. She pointed out that immigration is "controversial" at the state and federal levels and "that's why we're not involved." Another Executive Director stated that some organizations in her city plan advocacy events, but, from her perspective, "there is some fear about doing that and how that is going to end up representing the organization."

Engaging in policy advocacy can also be perceived as risky for the organization, especially if it is a departure from what has been done in the past or outside the scope of the organization's mission. In South Carolina's relatively small cities and towns, an organization's activities are noticed. Advocating for immigrant rights has implications for how the community in general-and potential clients, in particular-view one's organization and who it serves. The literacy center Director introduced above stated, "It's not a spoken rule here, but the previous director didn't want us branching into [advocacy] because we had such a public relations problem about being viewed as a, you know, an immigrant-only resource.” Another respondent avoids policy advocacy because immigration is controversial, particularly because much of the debate concerns legal status. Taking a position on this issue can be problematic, she explains. By advocating for immigrant rights, she is concerned she might be "advocating for unlawful behavior" of unauthorized immigrants, with the implication that the community will view her and her organization as morally inconsistent. Another respondent balked when asked if she is aware of state or local policies that affect immigrants in South Carolina. She answered that she knows of these policies but "would rather not comment." She is concerned that answering that question would affect the reputation of her organization as "neutral" and "impartial."

Similarly, other reasons for noninvolvement in policy advocacy boil down to a calculation of risk rather than ignorance of need. For example, a school social worker stated "I'm working for a school district-I could get in trouble." Another respondent explained "as a state employee sometimes it's not-sometimes it can be very uncool to be politically active. And not necessarily dangerous for you as an individual, but dangerous for your institution.” A few respondents said that policy advocacy activities were outside of their role or their organization's mission. A medium-sized health services organization had been involved with statewide coalitions in the past, but was too busy at the time of our interview 
to be involved. The Executive Director sees the topic of immigration "as controversial right now with some of the dialogues going on at the state level and national level," but his organization does not engage "in the justice stuff" because "we don't really see that as our focus." He explains that the controversy itself is not the reason why his organization chose not to engage in policy advocacy. Rather, "we're trying to focus on our mission.” Until the board decides that this is an issue which falls within their organization's purview, the organization will not pursue it. Another Director clarified that advocating for immigrant rights requires an understanding of "the legacy of the politics of oppression here [in South Carolina], and the stereotypes and how people are pretty comfortable with the stereotypes." Miscalculating these politics can be risky for an organization.

One program manager stated that she has not participated in organizational activities or conversations related to immigrant rights because her role is to "teach and manage the English as a second language program,” not engage in advocacy. Like many respondents who are not involved with coalitions, she knows about a local coalition and her organization has a relationship with them but is not involved. In other instances of noninvolvement, however, respondents stated that they had not been "invited" to join, or had not even heard of any such coalitions. Although these organizations serve immigrants, respondents were unaware of efforts in their area or across the state to coordinate services, build network connections, and address structural factors impeding immigrant access to support. These organizations may still be reluctant to join, for some of the same reasons described above. A manager of a local food pantry explained that their organization might be open to attending a future event aimed at helping the immigrant community, but not at the cost of prioritizing one client group over another. As an organization, they are "concerned with making sure everybody gets food," not just immigrants. Similar to the concerns articulated earlier about misrepresenting an organization's mission, allocating time and resources to join a coalition focused on immigrant rights might signal that a provider is more invested in this demographic than other groups they serve. In sum, there are important stakes these organizations take into consideration when it comes to policy advocacy: capacity of an organization, political and organizational risks involved in political activities in the immigrant-restrictive context, and recognition of their roles in a limited manner.

\section{Overcoming barriers to advocacy}

Immigrant-serving organizations in South Carolina that participate in policy advocacy also acknowledge that there are barriers to this form of work, but they tend to find ways around these obstacles, or identify the extra steps required to addressing them. The Director of a legal advocacy organization explained that policy advocacy efforts in South Carolina require challenging the perception that civil rights belong only to citizens: "When we're advocating for the civil rights of the undocumented community we have to have that extra step of explaining that the reason that these are rights is that they're human rights." For others, explaining why they engage in advocacy is less about additional steps, and more a shift in tactics. For example, the lead case manager at one organization generally adopts a "positive perspective" to the possibility of changing the larger structures that impede immigrant integration. Her perspective is guided by the belief that individuals who are 
opposed to immigrants and immigration may reconsider their views. However, she admits "I can't just be positive all the time. There are times when we have to fight for our clients' rights.”

Among the $50 \%$ of organizations in our sample that participate in policy advocacy activities, the majority take an indirect approach to influencing policy. If insider tactics aim to change policy through direct contact with policymakers, indirect tactics represent a category of policy advocacy activities that aim to raise awareness about a policy issue and to help shape a possible solution through means such as public education, writing letters to the editor, and joining advocacy coalitions (Mosley, 2011). This indirect approach is not uncommon among organizations in other service sectors. For example, Mosley (2011) finds in her study of homelessness service providers that $84 \%$ participated in coalitions for the purposes of influencing public policy, and 58\% provided public education on policy issues.

Coalitions and public education were most common forms of policy advocacy among immigrant-serving providers in our study. The organizations who have been engaged with advocacy state that they have reaped numerous benefits from these partnerships, including information sharing, knowledge building, efficient labor division, organizational growth, and bringing about more structural changes. For example, a nonprofit organization that primarily serves children and families reported working closely with the local police department to raise awareness about immigrant rights. They also organize outreach events and information sessions to improve community relations with immigrants, started a local group aimed at promoting higher education among immigrant youth, and held a week-long conference on the topic.

Coalitions can provide networking opportunities that facilitate other forms of indirect advocacy. This can be particularly useful for small organizations that lack the resources to engage in advocacy, or providers that may perceive policy advocacy as risky, outside their organization's mission, or both. Among these organizations are those that were able to engage in advocacy because they partnered with other coalition members that were more outspoken about immigrant rights. One organization that provides educational services explained this indirect approach offers some "cover" given that advocacy is not strictly part of her organization's mission:

It's tricky because our organization-we're not an advocacy organization, so those conversations [about policy advocacy] don't really take place here. But I have definitely had those kinds of conversations with other organizations and other community partners. It's interesting the way that [my organization] is moving. We can't directly advocate, but one thing that I'm very excited about that we're doing is in conjunction with [another local provider]. We're hosting a community forum...that is geared towards business leaders...[to] educate those business leaders about the economic contributions of a Latino community-which is not advocacy, per se, but at least it is a kind of awareness-building for people who may not be very knowledgeable about the [immigrant] community.

As this Project Coordinator notes, she did not view her collaborative efforts to raise awareness about the immigrant community as "advocacy" per se. However, her more 
narrow definition of advocacy also allows her to justify that this indirect tactic is still within (or at least not in contradiction with) her organization's mission.

Similarly, many of the respondents that reported participating in indirect forms of advocacy explained that more direct forms of advocacy were out of reach, or did not view their coalition work as advocacy. For example, a medium-sized provider that works with children and families participates in a local provider networking meeting aimed at serving Latino immigrants. However, the organization is wary of more direct forms of policy advocacy, or of even describing their coalition work as a form of policy advocacy at all. The Executive Director explained that they have to "answer to a board" and advocating more publicly for immigrant rights would be politically contentious. Doing so would "probably hurt my organization from a private funding perspective... and then, ultimately, that would hurt the families that I'm trying to serve." As a result, their organization does not "take a stance on immigrant rights." Indeed, this rationale is an echo of why the noninvolved organizations (described above) do not engage in advocacy at all.

To overcome this barrier to joining coalitions focused on immigrant services and immigrant rights, some respondents who joined coalitions sometimes did so personally rather than as representatives of their organization. The Executive Director of a mediumsized nonprofit was hesitant to engage in advocacy because his organization is affiliated with the county. This fact, combined with the problem that there were no existing coalitions in his county that addressed the policy advocacy concerns of immigrants, prompted him to personally start his own coalition. He was careful to explain that this effort was unrelated to his capacity as Executive Director: “Actually, I shouldn't mention the [name of his organization]_it's just something that I'm doing on my own as a private citizen.” His strategy is to work with the Latino community rather than other organizational partnerships:

I have a 9 to 5 job like everyone else. I'm passionate about the [immigrant] community, but things change. People go, positions change, organizations come and go. But if we could ignite that passion for advocacy in our clientele...I think we are leaving the community better off.

He views this grassroots approach to coalition-building as a way to give immigrants "voice" so they can "rise up and take ownership of the situation." His grassroots approach might also help avoid the possibility that coalitions, however well-meaning, may erroneously assume that they rightfully speak on behalf of the interests of immigrants (Mosley, 2013). However, his primary motivation for starting his own coalition is because the organization with which he is formally affiliated would be unwilling to let him do so.

Respondents in our sample were organizations involved with local coalitions do not even attend monthly meetings regularly. At times, limited involvement was attributable to organizational capacity, but others stated that the coalitions themselves were inconsistently active or ineffective. Coalitions are not always able to keep member organizations engaged and involved. One program manager stated that she is interested in working with a statewide coalition on policy advocacy, "but since I signed up probably a year and half ago I have not heard anything. I don't know if there's a glitch with that or if they haven't done anything." A number of providers stated that they had been involved with local or state- 
wide coalitions in the past, but no new information had been shared about coalition activities, so they were not sure where things stood. For others, the added burden of coalition-related tasks is untenable. The court liaison for an organization that addresses domestic violence explained that she feels inspired when she attends statewide coalition meetings, and finds the conversation productive. However, upon returning to her office the weight of other demands makes it difficult for her-and other coalition members - to carry that momentum out: "I've gone there [to coalition meetings] and really gotten excited about some new ideas, and then just come back and been so overwhelmed that I can't concentrate any of my time on it." Others admit that they have dropped out of some coalitions, especially if they do not seem to be "really moving forward on things." An attorney at a nonprofit legal justice organization admits that this is a difficult bar for many policy advocacy coalitions in the state to meet, but this particularly true in the case of immigration rights. Her organization helped to found a statewide coalition in response to the antiimmigrant legislation that was passed in South Carolina in 2011. The coalition was successful because there was a clear target, but when the threat of this policy subsided the coalition lost momentum:

It [the coalition] was very effective because we had something going on. We had something tangible for people to do...I do think that when people have something to do, when there is something big going on, they will pull together. But it's that down time where people have a hard time getting together.

As a result, several organizations in our study that have a history of involvement with coalitions express an openness to future collaborations even if they are not currently engaged in policy advocacy. For example, the Director of a large health services organization said he is familiar with the work of some local coalitions engaged in political advocacy on behalf of immigrants and has partnered with some members of a local coalition in the past. However, his organization was not formally involved in the coalition at the time of the interview. He stated that he would be willing to host a community event related to immigrant rights advocacy, but another organization would need to initiate the event and plan the details. That is, like other organizations in our sample, their involvement in policy advocacy is only periodic. This could change, however, if the issue of policy advocacy becomes more salient in the future. The same Director reflected that his organization joined a statewide advocacy effort when South Carolina enacted antiimmigrant state policies: "And so it [immigration] seemed to be more of a divisive issue, and we continued to treat people and to work with them as we had before, but the conversation and all things changed." Policy shifts in the future may trigger more coalition involvement because there is a clearly-defined issue around which coalition members can rally.

\section{Discussion and Conclusion}

In this paper, we explored the policy advocacy involvement of immigrant-serving organizations in South Carolina, a state with restrictive immigration legislation. The process of immigrant integration can be difficult and destabilizing for immigrant newcomers no matter where they settle, but those who live in receiving contexts with harsh, anti-immigrant laws such as South Carolina may be in even greater need of support. Our 
study is premised on the notion that local organizations that engage in political activities can influence public policy (Marwell, 2004; Mosley, 2012). To the extent that this is the case, these organizations can function as intermediaries between vulnerable groups and restrictive policy structures (Reid, 2000)—minimizing this barrier to immigrant integration.

Consistent with the literature on social service organizations as intermediaries, we find that immigrant-serving social service providers in our study are positioned to mediate between immigrants and the restrictive policy context. However, not all organizations engage in advocacy activities to advance the rights of immigrants in South Carolina. We find that organizations that engage in advocacy adopt a variety of tactics, but most respondents reported that their advocacy approach was indirect and non-confrontational. Coalition membership was one of the most common forms of advocacy, but even this was limited. Consistent with other studies, we find that involvement depends on factors such as organizational size, funding sources, the willingness of organizational leaders, and their willingness to collaborate (Mosley, 2010, 2013). We also find that while some local social service providers may engage in policy advocacy, others engage in advocacy efforts focused only on the needs of the clients they serve rather than the larger community of which their clients are a part-a common pattern among service providers in other contexts (Garrow \& Hasenfeld, 2014). Still other providers in our study do not engage in policy advocacy at all, despite their acknowledgement of harsh anti-immigrant laws in South Carolina.

The limitations of our study prevent us from generalizing these findings to immigrantserving organizations across the entire state. Our sample of immigrant-serving organizations is not representative, and the self-report nature of the data introduces the possibility of response bias. In addition, our study does not measure the impact of these policy advocacy activities on the laws and other structures that impact immigrant integration in South Carolina. However, other studies suggest that participation in coalitions can be an effective indirect form of policy advocacy (Fyall, 2016), particularly when individual organizations see more independent forms of advocacy to be risky. Indeed, these types of collaborative practices have increased within the field of policy advocacy (Mosely, 2013), and this is common practice for many organizations in our sample. However, because of data limitations in this study, it is unclear the extent to which these coalitions are actively pursuing a social justice agenda to advance immigrant rights in the state. Rather than engaging in serious policy advocacy activities, it is possible that these coalitions merely provide opportunities for sharing information about resources and discussing case-specific problems concerning immigrant clients. Yet, given that many organizations in this study report episodic involvement in policy advocacy, it is possible that the coalitions are similarly responsive to changes in the policy environment. For this reason, staying involved with coalitions when there is a "lull" may lead to more policy advocacy activities in the future if and when the coalition is compelled to take up a policy advocacy cause. Likewise, organizations that are not currently active in coalitions may rejoin when the coalition rallies around a pressing need for policy advocacy. For these reasons, coalition meetings focused merely on networking may perform an important function in the service of future policy advocacy activities by maintaining organizational 
ties and working relationships. Given this possibility, future research should explore the elasticity of policy advocacy activities in response to changes in the policy environment.

Consistent with other studies, we also find that many organizations in our sample do not participate in policy advocacy. Some respondents stated that they do not participate in advocacy at all simply because they do not think advocacy involvement should be centralor even peripheral - to their activities. Other reasons they offered were also consistent with the literature, including a lack of knowledge about policy and the policymaking process, organizational capacity, concern for displeasing an external funder, and fear of violating laws (Bass, Arons, Guinane, Carter, \& Rees, 2007; Mosley, 2010; Schneider \& Lester, 2001). Recognizing the general trend that advocacy is regarded as a peripheral function of a service provider's operations, future research must continue to assess noninvolvement among immigrant-serving organizations by comparing different receiving contexts. This includes examining differences between new destinations and traditional immigrant gateways, as well as places with active statewide coalitions, such as Illinois and Tennessee, relative to places without a unifying mechanism that can channel resources and strategically address immigrant rights concerns. Finally, research should explore whether there is a tipping point for immigrant-serving organizations-when the balance of cost/benefit considerations prompt a provider to decide to engage in advocacy. If so, what are the factors and conditions that predict this type of organizational behavior?

It is critical for the social work profession to pursue these questions in light of current immigration trends and policy. Social workers uphold social justice as a defining feature of professional practice, yet social service organizations are only modestly engaged in policy advocacy vis-à-vis immigrant rights. Through their daily work, social workers often directly witness or hear about the injustices immigrants face and are well-situated to explain these injustices to the broader society. Consequently, social workers and the administrators of social service organizations should be actively engaged in coalitions that advocate for immigrant rights. This is particularly important in places such as South Carolina with restrictive anti-immigrant laws. Providers should also continue to expand their policy advocacy actions to more directly address policy inequalities facing immigrants. For some organizations that assume certain types of advocacy activities are impermissible, this might require that they begin by reviewing what types of direct and indirect actions are allowed within the laws which govern what is defined as "lobbying" by the IRS.

Given the importance of policy advocacy to challenging and improving the structural conditions for immigrant integration, it is critical that social workers bridge the gap between what we profess to be important and what we prioritize in practice. This yawning gap is particularly noticeable in the face of immigrant rights. Social work practitioners need to raise awareness about policy advocacy and encourage their organizations to engage in advocacy practice that protects and enforces these rights.

\section{References}

Alba, R., \& Nee, V. (2003). Remaking the American mainstream: Assimilation and contemporary immigration. Cambridge: Harvard University Press. doi: https://doi.org/10.4159/9780674020115. 
Allard, S. (2009). Out of reach: Place, poverty, and the new American welfare state. New Haven: Yale University Press.

Allard, S., \& Roth, B. J. (2010). Suburbs in need: Rising suburban poverty and challenges for the safety net. Washington, D.C.: Brookings Institution.

Almog-Bar, M., \& Schmid, H. (2014). Advocacy activities of nonprofit human service organizations: A critical review. Nonprofit and Voluntary Sector Quarterly, 43(1), 11-35. doi: https://doi.org/10.1177/0899764013483212.

Bass, G. D., Arons, D. F., Guinane, K., Carter, M. F., \& Rees, S. (2007). Seen but not heard: Strengthening nonprofit advocacy. Washington, DC: The Aspen Institute.

Berry, J. M. (2005). Nonprofits and civic engagement. Public Administration Review, 65(5), 568-578. doi: https://doi.org/10.1111/j.1540-6210.2005.00484.X.

Berry, J. M., \& Arons, D. F. (2003). A voice for nonprofits. Washington, D.C.: Brookings Institution Press.

Boris, E., \& Mosher-Williams, R. (1998). Nonprofit advocacy organizations: Assessing the definitions, classifications, and data. Nonprofit and Voluntary Sector Quarterly, 27(4), 488-506. doi: https://doi.org/10.1177/0899764098274006.

Cabell, M. G. (2007). Mexican immigrant integration in the U.S. southeast: Institutional approaches to immigrant integration in Owensboro, Kentucky. Retrieved from The Center for Comparative Immigration Studies website https://ccis.ucsd.edu/ files/wp153.pdf.

Castles, S., \& Miller, M. J. (2009). The age of migration: International population movements in the modern world (4th ed.). New York, NY: The Guilford Press.

Cordero-Guzman, H. R. (2005). Community-based organisations and migration in New York City. Journal of Ethnic and Migration Studies, 31(5), 889-909. doi: https://doi.org/10.1080/13691830500177743

de Graauw, E. (2008). Nonprofit organizations: Agents of immigrant political incorporation in urban America. In S. K. Ramakrishnan \& I. Bloemraad (Eds.), Civic hopes and political realities: Immigrants, community organizations, and political engagement (pp. 323-350). New York: Russell Sage Foundation.

de Graauw, E. (2014). Municipal ID cards for undocumented immigrants: Local bureaucratic membership in a federal system. Politics \& Society, 42(3), 309-330. doi: https://doi.org/10.1177/0032329214543256

de Leon, E., Maronick, M., De Vita, C. J., \& Boris, E. T. (2009). Community-based organizations and immigrant integration in the Washington, D.C. metropolitan area. Washington, D.C.: The Urban Institute. doi: https://doi.org/10.1037/e726282011$\underline{001}$

Frasure, L. A., \& Jones-Correa, M. (2010). The logic of institutional interdependency: The case of day laborer policy in suburbia. Urban Affairs Review, 45, 451-482. doi: https://doi.org/10.1177/1078087409355640. 
Fyall, R. (2016). The power of nonprofits: Mechanisms for nonprofit policy influence. Public Administration Review, 76(6), 938-948. doi: https://doi.org/10.1111/puar.12550

Garrow, E. E., \& Hasenfeld, Y. (2014). Institutional logics, moral frames, and advocacy: Explaining the purpose of advocacy among nonprofit human-service organizations. Nonprofit and Voluntary Sector Quarterly, 43(1), 80-98. doi: https://doi.org/10.1177/0899764012468061.

Glaser, B. G. (1965). The constant comparative method of qualitative analysis. Social Problems, 12(4), 436-445. doi: https://doi.org/10.2307/798843.

Gleeson, S., \& Bloemraad, I. (2012). Assessing the scope of immigrant organizations: Official undercounts and actual underrepresentation. Nonprofit and Voluntary Sector Quarterly, 42(2), 346-370. doi: https://doi.org/10.1177/0899764011436105.

Hall, M. (2013). Residential integration on the new frontier: Immigrant segregation in established and new destinations. Demography, 50(5), 1873-1896. doi: https://doi.org/10.1007/s13524-012-0177-x

Hung, C.-K. R. (2007). Immigrant nonprofit organizations in U.S. metropolitan areas. Nonprofit and Voluntary Sector Quarterly, 36, 707-729. doi: https://doi.org/10.1177/0899764006298962.

Illegal Immigration Reform Act, H. 4400, 117th Leg. $2^{\text {nd }}$ Sess. (2008).

Kobach, K. W. (2008). Attrition through enforcement: A rational approach to illegal immigration. Tulsa Journal of Comparative \& International Law, 15, 155-163.

Largen, S. (2012, October 12). New S.C. law unit arresting illegals. Post and Courier. Retrieved from https://www.postandcourier.com/archives/new-s-c-law-unitarresting-illegals/article_39331aae-5ca5-5126-8bd0-32aec5240346.html

Lewis, P. G., Provine, D. M., Varsanyi, M. W., \& Decker, S. H. (2013). Why do (some) city police departments enforce federal immigration law? Political, demographic, and organizational influences on local choices. Journal of Public Administration Research and Theory, 23(1), 1-25. doi: https://doi.org/10.1093/jopart/mus045.

Lichter, D., Parisi, D., Taquino, M., \& Grice, S. M. (2010). Residential segregation in new Hispanic destinations: Cities, suburbs, and rural communities compared. Social Science Research, 39, 215-230. doi: https://doi.org/10.1016/j.ssresearch.2009.08.006

Lietz, C. A., \& Zayas, L. E. (2010). Evaluating qualitative research for social work practitioners. Advances in Social Work, 11(2), 188-202.

MacIndoe, H., \& Whalen, R. (2013). Specialists, generalists, and policy advocacy by charitable nonprofit organizations. Journal of Sociology and Social Welfare, 40(2), 119-149.

Marrow, H. B. (2005). New destinations and immigration incorporation. Perspectives on Politics, 3, 781-799. doi: https://doi.org/10.1017/S1537592705050449. 
Marrow, H. B. (2009). Immigrant bureaucratic incorporation: The dual roles of professional missions and government policies. American Sociological Review, 74, 756-776. doi: https://doi.org/10.1177/000312240907400504

Marrow, H. B. (2013). Assimilation in new destinations. Daedalus, 142(3), 107-122. doi: https://doi.org/10.1162/DAED a 00222

Martin, N. (2012). “There is abuse everywhere”: Migrant nonprofit organizations and the problem of precarious work. Urban Affairs Review, 48(3), 389-416. doi: https://doi.org/10.1177/1078087411428799

Marwell, N. P. (2004). Privatizing the welfare state: Nonprofit community-based organizations as political actors. American Sociological Review, 69, 265-291. doi: https://doi.org/10.1177/000312240406900206

Massey, D. S. (2008). New faces in new places: The changing geography of American immigration. New York: Russell Sage Foundation.

Massey, D. S., Arango, J., Hugo, G., Kouaouci, A., Pellegrino, A., \& Taylor, J. E. (1994). An evaluation of international migration theory: The North American case. Population and Development Review, 20(4), 699-751. doi: https://doi.org/10.2307/2137660.

Mellinger, M. S. (2014a). Beyond legislative advocacy: Exploring agency, legal, and community advocacy. Journal of Policy Practice, 13(1), 45-58. doi: https://doi.org/10.1080/15588742.2013.855887.

Mellinger, M. S. (2014b). Do nonprofit organizations have room for advocacy in their structure? An exploratory study. Human Services Organizations Management, Leadership \& Governance, 38(2), 158-168. doi: https://doi.org/10.1080/03643107.2013.859197.

Migration Policy Institute. (2018). State Immigration Data Profiles. Tabulations from the U.S. Census Bureau's American Community Survey (ACS), 2015. Retrieved from http://www.migrationpolicy.org/programs/data-hub/us-immigration-trends\#history

Miles, M. B., \& Huberman, A. M. (1994). Qualitative data analysis. Thousand Oaks: Sage.

Mitnik, P. A., \& Halpern-Finnerty, J. (2010). Immigration and local governments: Inclusionary local policies in the era of state rescaling. In M. W. Varsanyi (Ed.), Taking local control: Immigration policy activism in U.S. cities and states (pp. 5172). Stanford, CA: Stanford University Press.

Mosley, J. (2013). Recognizing new opportunities: Reconceptualizing policy advocacy in everyday organizational practice. Social Work, 58(3), 231-239. doi: https://doi.org/10.1093/sw/swt020.

Mosley, J. E. (2010). Organizational resources and environmental incentives: Understanding the policy advocacy involvement of human service nonprofits. Social Service Review, 84(1), 57-76. doi: https://doi.org/10.1086/652681. 
Mosley, J. E. (2011). Institutionalization, privatization, and political opportunity: What tactical choices reveal about the policy advocacy of human service nonprofits. Nonprofit and Voluntary Sector Quarterly, 40(3), 435-457. doi: https://doi.org/10.1177/0899764009346335

Mosley, J. E. (2012). Keeping the lights on: How government funding concerns drive the advocacy agendas of nonprofit homeless service providers. Journal of Public Administration Research and Theory, 22(4), 841-866. doi: https://doi.org/10.1093/jopart/mus003

Mosley, J. (2013). Recognizing New Opportunities: Reconceptualizing Policy Advocacy in Everyday Organizational Practice. Social Work, 58(3), 231-239. doi: https://doi.org/10.1093/sw/swt020.

National Immigration Law Center. (2014). Civil Rights Coalition achieves important protections against South Carolina's anti-immigrant law. Retrieved from https://www.nilc.org/2014/03/03/nr030314/.

Portes, A., \& Rumbaut, R. (2006). Immigrant America: A portrait (3rd ed.). Berkeley: University of California Press.

Portes, A., \& Zhou, M. (1993). The new second generation: Segmented assimilation and its variants. The Annals of the American Academy of Political \& Social Science, 530, 74-96. doi: https://doi.org/10.1177/0002716293530001006

Ramakrishnan, S. K., \& Wong, T. (2010). Partisanship, not Spanish: Explaining municipal ordinances affecting undocumented immigrants. In M. W. Varsanyi (Ed.), Taking local control: Immigration policy activism in U.S. cities and states (pp. 7396). Stanford, CA: Stanford University Press.

Reid, E. J. (2000). Nonprofit advocacy and political participation. In E. T. Boris \& C. E. Steuerle (Eds.), Nonprofits and government: Collaboration and conflict (pp, 291325). Washington, DC: Urban Institute.

Roth, B. J., \& Allard, S. W. (2016). (Re)defining access to Latino immigrant-serving organizations: Evidence from Los Angeles, Chicago, and Washington, DC. Journal of the Society for Social Work and Research, 7(4), 729-753. doi: https://doi.org/10.1086/689358.

Roth, B. J., Gonzales, R. G., \& Lesniewski, J. (2015). Building a stronger safety net: Local organizations and the challenges of serving immigrants in the suburbs. Human Service Organizations: Management, Leadership \& Governance, 39(4), 348-361. doi: https://doi.org/10.1080/23303131.2015.1050143

Schneider, R. L., \& Lester, L. (2001). Social work advocacy: A new framework for action. Pacific Grove, CA: Brooks/Cole.

Singer, A. (2013). Contemporary immigrant gateways in historical perspective. Daedalus, 142, 76-91. doi: https://doi.org/10.1162/DAED_a_00220

Varsanyi, M. W. (2008). Immigration policing through the backdoor: City ordinances, the 
"Right to the City," and the exclusion of undocumented day laborers. Urban Geography, 29, 29-52. doi: https://doi.org/10.2747/0272-3638.29.1.29.

Varsanyi, M. W. (2011). Neoliberalism and nativism: Local anti-immigrant policy activism and an emerging politics of scale. International Journal of Urban and Regional Research, 35, 295-311.

Varsanyi, M. W., Lewis, P. G., Provine, D., \& Decker, S. (2012). A multilayered jurisdictional patchwork: Immigration federalism in the United States. Law \& Policy, 34(2), 138-158. doi: https://doi.org/10.1111/j.1467-9930.2011.00356.X.

Yoshikawa, H., \& Kalil, A. (2013). The effects of parental undocumented status on the developmental contexts of young children in immigrant families. Child Development Perspectives, 5, 291-297.

Author note: Address correspondence to: Benjamin J. Roth, PhD, College of Social Work, University of South Carolina, 1512 Pendleton St., Columbia, SC 29208. rothbj@sc.edu. 